\title{
Sistem Informasi Persediaan Obat dengan Metode Naïve Bayes Pada RSUD Tanjungpinang
}

\author{
Isron Al Miraz Siregar ${ }^{1}$, Elvianna ${ }^{2}$, Nurul Saepul ${ }^{3}$ \\ 1,2,3 Jurusan Teknik Informatika Sekolah Tinggi Teknologi Indonesia Tanjungpinang \\ Jln. Pompa Air No. 28 Tanjungpinang Kepulauan Riau Indonesia \\ 1isron86@gmail.com \\ ²elvianna@sttindonesia.ac.id \\ ${ }^{3}$ saepul@sttindonesia.ac.id
}

\begin{abstract}
Intisari- Sistem pengolahan data yang ada pada Apotek RSUD tanjungpinang yang terintergrasi belum dapat memprediksi stok obat. Sistem prediksi data obat berdasarkan dari penjulan obat dan dari rata-rata penjualan obat. Alasan menggunakan metode naïve bayes adalah karena metode ini memberikan kemudahan dalam menghitung dan menentukan kemungkinan-kemungkinan yang terjadi di apotek RSUD Tanjungpinang serta dapat membantu apotek dalam mengambil keputusan untuk melakukan transaksi pembelian obat. Pengembangan sistem informasi dalam pembuatan perangkat lunak menggunakan metode Waterfall. Aplikasi pengembangannya menggunakan netbeans 7.3.1 dan MySQL sebagai databas. Program diuji dengan metode Black Box. Dengan adanya aplikasi ini dapat membantu pihak apotek dalam melakukan pendataan data obat dengan cepat dan tepat serta dapat membantu melakukan prediksi data obat menggunakan metode naïve bayes untuk mengambil keputusan dalam melakukan pembelian obat. Serta dapat membuat laporan yang nanti diserahkan kepada pimpinan.
\end{abstract}

Kata kunci- Prediksi, Apotek, NetBeans 7.3.1, MySQL.

Abstract - The integrated data processing system at the Tanjungpinang Hospital Pharmacy cannot predict the stock of drugs. Drug data prediction system is based on drug sales and drug sales rates. The reason for using the nä̈ve Bayes method is because this method makes it easy to calculate and determine the possibilities that occur at the Tanjungpinang Hospital pharmacy and can help the pharmacy in making decisions to make drug purchase transactions. The development of information systems in making software uses the Waterfall method. The development application uses netbeans 7.3.1 and MySQL as the database. The program was tested using the Black Box method. With this application, it can help the pharmacy to collect drug data quickly and accurately and can help predict drug data using the naïve Bayes method to make decisions in making drug purchases. And can make a report which will be submitted to the owner.

Keywords-Prediction, Pharmacy, NetBeans 7.3.1, MySQL.

\section{Pendahuluan}

Seiring dengan kemajuan teknologi, komputer merupakan produk teknologi yang mampu memecahkan masalah bukan hanya dalam segi perhitungan tetapi juga dalam kemampuannya menyimpan dan memberikan informasi. Walaupun demikian dalam masyarakat modern komputer lebih banyak dimanfaatkan sebagai pusat data (database) dibandingkan penggunaan lainnya. Karena peran database sangat menonjol. Pemrosesan basis data menjadi perangkat andalan yang kehadirannya sangat diperlukan, dan tidak hanya mempercepat pemerolehan informasi, tetapi juga dapat meningkatkan pelayanan kepada pelanggan.

Tempat penulis melakukan penelitian yaitu di RSUD Tanjungpinang bagian apotek. Fenomena yang terjadi saat ini adalah belum terkontrolnya ketersediaan obat dan kebutuhan kesehatan yang ada apotek RSUD Tanjungpinang karena masih harus mengecek ke gudang yang dilakukan oleh petugas apoteker sehingga sulit menentukan kapan stok akan habis. Dan juga saat melakukan pendataan stok obat dan kebutuhan kesehatan masih belum tersistem sehingga sulitnya mencari data persediaan stok obat di Apotek RSUD Tanjungpinang. Pembuatan laporan persediaan yang dihasilkan kurang terperinci sehingga menyulitkan pihak manajemen dalam mengambil keputusan tentang persediaan obat.[11] Sehingga dengan pembuatan sistem prediksi obat ini dapat membantu pihak Apotek RSUD Tanjungpinang menangani persediaan obat yang dilakukan secara berkala.

Dalam membuat sistem informasi ini menggunakan NetBeans yang merupakan IDE (Integrated Development Environment) untuk membuat aplikasi dengan Java, PHP, C, $\mathrm{C}++$, dan HTML5. Secara garis besar, NetBeans IDE bekerja menyerupai Microsoft Visual Studio maupun Dreamweaver dalam konteks sebagai aplikasi yang memiliki lingkungan kerja lengkap untuk membangun aplikasi lain. NetBeans dimulai pada tahun 1996 sebagai Xelfi yang merupakan proyek IDE pada Universitas Charles di Praha. Pada tahun 1997, Roman Stanek mengomersialkan IDE NetBeans dan kemudian dibeli oleh Sun Microsystem pada tahun 1990. Pada tahun 2010, Sun (dan NetBeans) diakuisisi oleh Oracle.[4]

Bahasa pemograman yang digunakan adalah Java. Java merupakan bahasa pemrograman tingkat tinggi (high level), artinya bahasa ini mudah dipahami oleh manusia pada umumnya , karena menggunakan bahasa sehari-hari manusia. Java dulu dibuat oleh perusahaan Sun Microsystem, oleh James Ghosling ,Patrick Naughton, dan Mike Sheridan pada 
tahun 1991, untuk mengembangkan versi pertama dari Java yang dulu bernama Oak, yang dimana sekarang Java diakuisisi oleh perusahaan Oracle[3] serta menggunakan metode Algoritma Naive Bayes Classifiers merupakan salah satu algoritma yang terdapat pada teknik klasifikasi. Naive Bayes merupakan pengklasifikasian dengan metode probabilitas dan statistik yang dikemukan oleh ilmuwan Inggris Thomas Bayes, yaitu memprediksi peluang di masa depan berdasarkan pengalaman dimasa sebelumnya sehingga dikenal sebagai Teorema Bayes. Teorema tersebut dikombinasikan dengan Naïve bayes dimana diasumsikan kondisi antar atribut saling bebas[5]

Dalam kesehariannya, kata sistem informasi sering dikaitkan dengan sistem yang berbasis komputerisasi. Akan tetapi, sistem informasi tidaklah harus melibatkan komputer. Menurut (O’Brian, 2005), Sistem Informasi adalah kombinasi antara prosedur kerja, informasi, orang dan teknologi informasi yang diorganisasikan untuk mencapai tujuan dalam sebuah organisasi.[7] Secara sederhana sistem dapat diartikan sebagai suatu kumpulan atau himpunan dari unsur atau variabelvariabel yang saling terorganisasi, saling berinteraksi, dan saling bergantung sama lain .[12] Menurut Hartono sistem adalah suatu kesatuan yang terdiri dua atau lebih komponen atau subsistem yang berinteraksi untuk mencapai suatu tujuan .[13] Sedangkan informasi adalah data yang diolah menjadi bentuk yang lebih berguna dan lebih berarti bagi yang menerimanya. Dalam beberapa hal pengetahuan tentang peristiwa-peristiwa tertentu atau situasi yang telah dikumpulkan atau diterima melalui proses komunikasi yang didapatkan dari berita juga dinamakan informasi.[14]

Obat adalah benda atau zat yang dapat digunakan untuk merawat penyakit, membebaskan gejala, atau mengubah proses kimia dalam tubuh. Obat ialah suatu bahan atau paduan bahanbahan yang dimaksudkan untuk digunakan dalam menetapkan diagnosis, mencegah, mengurangkan, menghilangkan, menyembuhkan penyakit atau gejala penyakit, luka atau kelainan badaniah dan rohaniah pada manusia atau hewan dan untuk memperelok atau memperindah badan atau bagian badan manusia termasuk obat tradisional.[9] Jenis-jenis obat:

1. Obat Bebas

Obat Bebas ini sering disebut juga dengan obat daftar $F$ (Free= bebas) dimana oabat ini dijual bebas dan dapat dibeli tanpa resep dokter.

\section{Obat Bebas Terbatas}

Obat Bebas Terbatas merupakan obat-obatan dalam daftar obat W (Waarschuwig = Peringatan) dimana obat ini merupakan obat keras yang dapat diserahkan kepada pemakainya tanpa resep dokter.

\section{Obat Keras}

Obat Keras merupakan obat yang hanya dapat dibeli dengan RESEP DOKTER. Adapun penandaannya diatur berdasarkan KMK RI No. 02396/A/SK/VIII/1986 tentang tanda khusus Obat Keras daftar G (Gevaarlijk = Berbahaya) adalah lingkaran bulat berwarna merah dengan garis tepi dan terdapat huruf $\mathrm{K}$ yang menyentuh garis berwarna hitam.

4. Obat Psikotropika

Psikotropika adalah zat atau obatr, baik alamiah maupun sintetis bukan narkotika, yang berkhasiat psikoaktif melalui pengaruh selektif pada susunan saraf pusat yang menyebabkan perubahan khas pada aktivitas mental dan perilaku (UU No. 5 Tahun 1997).

\section{Obat Narkotika}

Narkotika adalah zat atau obat yang berasal dari tanaman atau bukan tanaman, baik sintetis maupun semi sintetis, yang dapat menyebabkan penurunan atau perubahan kesadaran, hilangnya rasa, mengurangi sampai menghilangkan rasa nyeri dan dapat menimbulkan ketergantungan yang dibedakan ke dalam golongan-golongan sebagaimana terlampir dalam UU tentang Narkotika ( UU No. 35 Tahun 2009).

Data mining didefinisikan sebagai sebuah proses untuk menemukan hubungan, pola dan tren baru yang bermakna dengan menyaring data yang sangat besar, yang tersimpan dalam penyimpanan, menggunakan teknik pengenalan pola seperti teknik statistik dan matematikan.[1] Pengelolaan data mining terdiri dari beberapa metode pengolahan yaitu:

1) Predictive Modelling yang merupakan pengolahan data mining dengan melakukan prediksi / peramalan. Tujuan metode ini untuk membangun model prediksi suatu nilai yang mempunyai cirri - ciri tertentu. Contoh algortimanya Linear Regression, Neural Network, Support Vector Machine, dan lain - lain.

2) Association (Asosiasi) merupakan teknik dalam data mining yang mempelajari hubungan antar data. Contoh penggunaannya seperti untuk menganalisis perilaku mahasiswa yang data terlambat. Contohnya jika mahasiswa memiliki jadwal dengan dosen $\mathrm{A}$ dan $\mathrm{B}$, maka mahasiswa akan datang terlambat. Contoh algortimanya FP-Growth, A priori, dan lain - lain.

3) Clustering (Klastering) atau pengelompokkan merupakan teknik untuk mengelompokkan data ke dalam suatu kelompok tertentu. Contoh algortimanya K-Means, $K$ Medoid, Self- Organitation Map (SOM), Fuzzy C-Means, dan lain - lain.

4) Deskripsi terkadang peneliti dan analisis secara sederhana ingin mencoba mencari cara untuk menggambarkan pola dan kecenderungan yang terdapat dalam data.sebagai contoh, petugas pengumpulan suara mungkin tidak dapat menemukan keterangan atau fakta bahwa siapa yang tidak cukup professional akan sedikit didukung dalam pemilihan presiden.

5) Estimasi model dibangun dengan menggunakan record lengkap yang menyediakan nilai dari variabel targetsebagai prediksi. Selanjutnya, pada peninjauan berikutnya estimasi nilai dari variabel target dibuat berdasarkan nilai variabel prediksi.

6) Classification terdapat variabel kategori. Sebagai contoh, penggolongan pendapatan dapat dipisahkan dalam tiga kategori, yaitu pendapatan tinggi, pendapatan sedang, dan pendapatan rendah.

7) Classification merupakan teknik mengklasifikasikan data. Perbedaannya dnegan metode clustering terletak pada data, dimana pada clustering variabel dependen tidak ada, sedangkan pada classification diharuskan ada variabel dependen. Contoh algortimanya yang menggunakan metode ini ID3 dan K-Nearest Neighbors.

Metode Bayes/Bayesian Classification adalah pengklasifikasian statistik yang dapat digunakan untuk memprediksi probabilitas keanggotaan suatu class. Bayesian Classification didasarkan pada teorema Bayes yang memiliki 
kemampuan klasifikasi serupa dengan Deicion Tree dan Neural Network. Bayesian Classification terbukti memiliki akurasi dan kecepatan yang tinggi saat diaplikasikan kedalam database dengan data yang besar.[10]

$$
\mathrm{P}(\mathrm{H} \mid \mathrm{X})=\frac{\mathrm{P}(\mathrm{H} \mid \mathrm{H}) \mathrm{P}(\mathrm{H})}{\mathrm{P}(\mathrm{X})}
$$

Gambar 1 Rumus Metode Naïve Bayes

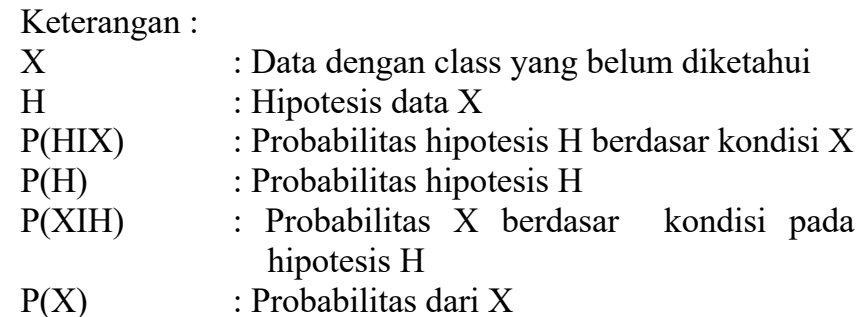

MySQL merupakan perangkat lunak yang juga bersifat open source. Sesuai namanya, bahasa standar yang digunakan adalah SQL (Structure Query Language), yang merupakan bahasa standar untuk pengolahan database. SQL menyediakan perintah untuk membuat database, field, ataupun index untuk menambah atau menghapus data menggunakan bahasa basis data atau yang sering kita dengar dengan sebutan DBMS (Database Management System).

Xampp adalah sebuah paket kumpulan software yang terdiri dari Apache, MySQL, Php MyAdmin, PHP, Perl, Felezilla dan lain-lain. Xampp berfungsi untuk memudahkan instalasi lingkungan PHP, di mana biasanya lingkungan pembangunan web memerlukan PHP, Apache, MySQL dan PhpMyAdmin serta software-software yang terkait dengan pengembangan web. Dengan menggunakan Xampp, pengguna tidak perlu menginstal aplikasi-aplikasi tersebut satu persatu. Paket aplikasi perlu di extract dan di install terlebih dahulu, dengan memilih jenis Xampp sesuai dengan jenis OS.[6] Setelah sukses menginstal Xampp, pengguna dapat langsung mengaktifkan $M y S Q L$.

\section{Metodologi Penelitian}

Metodologi penelitian merupakan suatu proses yang digunakan untuk memecahkan suatu masalah secara logis, dimana memerlukan data-data untuk mendukung terlaksananya suatu penelitian. Metodologi yang digunakan pada penelitian ini adalah metode:

\section{A. Metode Pengumpulan Data}

Dalam proses pengumpulan data ini penulis menggunakan cara yang sederhana untuk mendapatkan data-data dan informasi yang di inginkan. Data-data atau informasi yang didapat secara langsung maupun tidak langsung tersebut dapat di ambil atau yang diperoleh penulis melalui beberapa tahap yang dimaksud penulis diantaranya adalah sebagai berikut:

- Studi Pustaka yaitu untuk mengumpulkan data dan informasi yang berhubungan dengan masalah yang dibahas, dengan cara membaca dan memahami literature-literature dari beberapa buku.

- Wawancara, teknik pengumpulan data dengan cara memberikan beberapa pertanyaan langsung kepada pihak yang terkait maupun staf perusahaan atau instansi yang bersangkutan.

- Observasi (memantau), teknik pengumpulan data dengan melakukan pengamatan secara langsung atau turun kelokasi penelitian untuk mendapatkan data dan informasi yang lebih banyak dan akurat.

\section{B. Metode Pengembangan Perangkat Lunak}

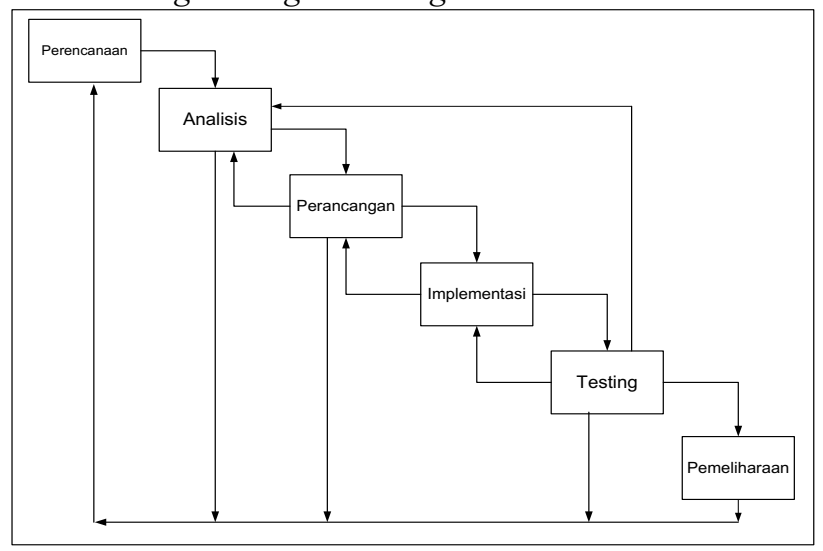

Gambar 1. Model Pengembangan Air Terjun[8]

Metode pengembangan perangkat lunak yang digunakan adalah metode Waterfall. Kelebihan dari metode ini adalah terstruktur, dinamis, dan sequential. Metode waterfall dapat dilihat pada gambar di halaman 10 yang terdiri dari beberapa tahap kegiatan antaran lain sebagai berikut[8] :

1. Requirement

Requirement (Analisis kebutuhan) yaitu merupakan salah satu langkah unuk menganalisa sebuah kebutuhan sistem. Pengumpulan data dalam tahap ini bisa melakukan sebuah penelitian, wawancara atau study literatur. Seorang analis akan menggali informasi sebanyak-banyaknya dari user sehingga akan tercipta sebuah sistem komputer yang bisa melakukan tugas-tugas yang diinginkan oleh user tersebut.

2. Design System

Design System (Desing sistem) adalah Proses desain yang akan menterjemahkan syarat kebutuhan kesebuah perancangan perangkat lunak yang dapat diperkirakan sebelum dibuat koding. Proses ini berfokus pada struktur data, arsitektur perangkat lunak, representasi interface, dan detail (algoritma) prosedural. Tahapan ini akan menghasilkan dokumen yang disebut software requirement.

3. Coding dan Testing

Coding dan Testing (Penulisan Sintak atau kode program dan implementasi) yaitu merupakan penerjemahan design dalam bahasa yang bisa dikenali oleh computer yang dilakukan oleh programmer yang akan meterjemahkan transaksi yang diminta oleh $u$ ser. Tahapan inilah yang merupakan tahapan secara nyata dalam mengerjakan suatu sistem.Dalam artian penggunaan computer akan dimaksimalkan dalam tahapan ini.

4. Penerapan dan Pengujian Program

Penerapan dan Pengujian Program (Integration and Testing) adalah Tahapan yang bisa dikatakan final 
dalam pembuatan sebuah sistem. Setelah melakukan analisa, design dan pengkodean maka sistem yang sudah jadikan digunakan oleh user.

5. Pemeliharaan

Pemeliharaan (Operation and Maintenance) adalah Perangkat lunak yang susah disampaikan kepada pelanggan pasti akan mengalami perubahan. Perubahan tersebut bisa karena mengalami kesalahan karena perangkat lunak harus menyesuaikan dengan lingkungan (periperal atau sistem operasi) baru, atau karena pelanggan membutuhkan perkembangan fungsional.

\section{HASIL DAN PEMBAHASAN}

\section{A. Perhitungan Metode Naive Bayes}

Metode naïve bayes digunakan untuk mengetahui stok obat yang ada apoteker melakukan perhitungan penjualan obat perbulannya sehingga dapat menetukan prediksi obat yang ada di apotek. Untuk mempermudah dalam proses penggunaan metode naïve bayes maka data perlu digunakan sebagai perbandingan lalu dilakukan proses konversi ke dalam bentuk yang dapat diolah dengan proses naïve bayes yang ada pun tahap nya sebagai berikut:

1. Nama Obat

Nama obat diliat berdasarkan jenis obat yang akan di hitung jumlah stoknya dengan naïve bayes.

\section{Produk}

Produksi obat yang dibuat. Contoh Kimia farma.

3. Satuan

Satuan berdasarkan kemasan obat. Contoh Tablet, Box, syrup.

\section{Golongan}

Golongan obat adalah penggolongan yang dimaksudkan untuk peningkatan keamanan dan ketepatan penggunaan serta pengamanan distribusi. Contoh Obat Bebas.

5. Jenis Obat

Jenis berdasarkan penyakit obat.

6. Stok

Stok yang tersedia diapotek perbulannya.

7. Keterangan

Menghitung jumlah stok yang akan di klasifikasi cukup atau tidak cukup.

TABEL I

KETERANGAN

\begin{tabular}{cc}
\hline No & Keterangan \\
\hline $\mathbf{1}$ & Cukup \\
$\mathbf{2}$ & Tidak Cukup \\
\hline
\end{tabular}

\begin{tabular}{|c|c|c|c|c|c|c|c|}
\hline No & $\begin{array}{c}\text { Nama } \\
\text { Obat }\end{array}$ & Produk & Satuan & Golongan & Jenis & Stok & $\begin{array}{l}\text { Keter } \\
\text { angan }\end{array}$ \\
\hline 1 & $\begin{array}{c}\text { Paraceta } \\
\text { mol }\end{array}$ & $\begin{array}{l}\text { Kimia } \\
\text { farma }\end{array}$ & Tablet & $\begin{array}{c}\text { Obat } \\
\text { bebas }\end{array}$ & $\begin{array}{c}\text { Obat } \\
\text { demam }\end{array}$ & 14000 & CưRup \\
\hline 2 & $\begin{array}{c}\text { Paraceta } \\
\text { mol }\end{array}$ & $\begin{array}{l}\text { Kimia } \\
\text { farma }\end{array}$ & Tablet & $\begin{array}{l}\text { Obat } \\
\text { bebas }\end{array}$ & $\begin{array}{c}\text { Obat } \\
\text { demam }\end{array}$ & 1000 & Cukup \\
\hline 3 & $\begin{array}{c}\text { Paraceta } \\
\text { mol }\end{array}$ & $\begin{array}{l}\text { Kimia } \\
\text { farma }\end{array}$ & Tablet & $\begin{array}{l}\text { Obat } \\
\text { bebas }\end{array}$ & $\begin{array}{c}\text { Obat } \\
\text { demam }\end{array}$ & 1000 & Cukup \\
\hline 4 & $\begin{array}{c}\text { Paraceta } \\
\text { mol }\end{array}$ & $\begin{array}{l}\text { Kimia } \\
\text { farma }\end{array}$ & Tablet & $\begin{array}{l}\text { Obat } \\
\text { bebas }\end{array}$ & $\begin{array}{c}\text { Obat } \\
\text { demam }\end{array}$ & 1000 & Cukup \\
\hline 5 & $\begin{array}{c}\text { Paraceta } \\
\text { mol }\end{array}$ & $\begin{array}{l}\text { Kimia } \\
\text { farma }\end{array}$ & Tablet & $\begin{array}{l}\text { Obat } \\
\text { bebas }\end{array}$ & $\begin{array}{c}\text { Obat } \\
\text { demam }\end{array}$ & 1000 & Cukup \\
\hline 6. & $\begin{array}{c}\text { Paraceta } \\
\text { mol }\end{array}$ & $\begin{array}{l}\text { Kimia } \\
\text { farma }\end{array}$ & Tablet & $\begin{array}{l}\text { Obat } \\
\text { bebas }\end{array}$ & $\begin{array}{c}\text { Obat } \\
\text { demam }\end{array}$ & 500 & $\begin{array}{l}\text { Tidak } \\
\text { Cukup }\end{array}$ \\
\hline 7. & $\begin{array}{c}\text { Paraceta } \\
\text { mol }\end{array}$ & $\begin{array}{l}\text { Kimia } \\
\text { farma }\end{array}$ & Syrup & $\begin{array}{l}\text { Obat } \\
\text { bebas }\end{array}$ & $\begin{array}{c}\text { Obat } \\
\text { demam }\end{array}$ & 600 & $\begin{array}{l}\text { Tidak } \\
\text { Cukup }\end{array}$ \\
\hline
\end{tabular}

Untuk menghitung algoritma naïve bayes dari sistem yang akan dibangun adalah sebagai berikut:

1. Menghitung nilai peluang kasus baru dari setiap data dengan class yang ada "P(Ci)".

2. Menghitung nilai akumulasi peluang dari setiap class "P(X|Ci)".

3. Menghitung nilai dari setiap class.

4.Menentukan class dari kasus tersebut.

Mengitung dari tabel 2 dengan metode naïve bayes :

a. Menghitung $\mathrm{P}(\mathrm{Ci})$

$\mathrm{P}($ Keterangan $=$ "CUKUP" $)=3 / 7=0.42$

$\mathrm{P}($ Keterangan $=$ "TIDAK CUKUP" $)=4 / 7=0.57$

b. Menghitung $\mathrm{P}(\mathrm{X} \mid \mathrm{Ci})$

$\mathrm{P}($ produk $=$ Kimia farma $\mid \mathrm{Y}=\mathrm{CUKUP})=3 / 7$

$\mathrm{P}($ produk $=$ Kimia farma $\mid \mathrm{Y}=\mathrm{TIDAK}$ CUKUP $)=4 / 7$

$\mathrm{P}($ satuan $=$ tablet $\mid \mathrm{Y}=\mathrm{CUKUP})=3 / 3$

$\mathrm{P}($ satuan $=$ tablet $\mid \mathrm{Y}=$ TIDAK CUKUP $)=3 / 4$

$\mathrm{P}($ golongan $=$ Obat bebas $\mid \mathrm{Y}=\mathrm{CUKUP})=3 / 7$

$\mathrm{P}($ golongan $=$ Obat bebas $\mid \mathrm{Y}=$ TIDAK CUKUP $)=4 / 7$

$\mathrm{P}($ Jenis $=$ Obat demam $\mid \mathrm{Y}=\mathrm{CUKUP})=3 / 7$

$\mathrm{P}($ Jenis $=$ Obat demam $\mid \mathrm{Y}=$ TIDAK CUKUP $)=4 / 7$

Cukup $=3 / 7 * 3 / 3 * 3 / 7 * 3 / 7=0.078$

Tidak cukup $=4 / 7 * 3 / 4 * 4 / 7 * 4 / 7=0.139$

c. $\mathrm{P}(\mathrm{x} \mid \mathrm{Ci})^{*} \mathrm{P}(\mathrm{Ci})$

$\mathrm{P}($ Keterangan $=$ "CUKUP” $) *$ Cukup $=0.42 * 0.078=0.032$

$\mathrm{P}($ Keterangan $=$ "TIDAK CUKUP") $*$ Tidak cukup $=$ $0.57 * 0.139=0.079$

d. Menghitung rata- rata penjualan untuk mengetahui stok obat yang akan bertahan.

e. Kesimpulannya adalah karena hasil P(Klasifikasi = "TIDAK CUKUP") lebih besar dari P(Klsifikasi = "CUKUP”) maka keputusannya "TIDAK CUKUP”.

\section{B. Flowmap Berjalan}

TABEL II

TABEL PENJUALAN OBAT

TABEL III

TABEL INPUTAN 


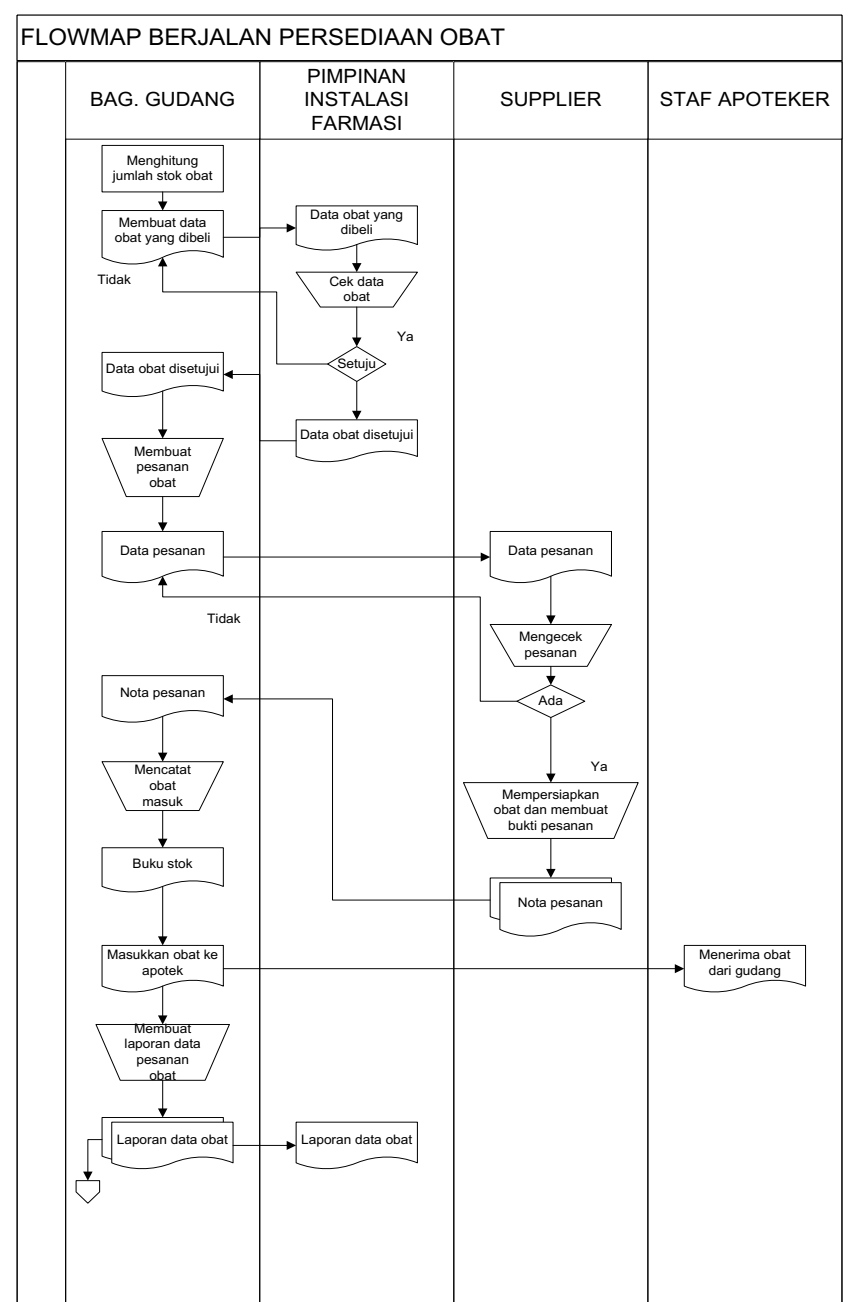

Gambar 3. Flowmap Berjalan Persediaan Obat

Prosedur Persediaan Obat Yang Sedang Berjalan:

1. Menghitung jumlah stok obat yang ada di gudang.

2. Bagian gudang memberikan data obat yang akan dibeli ke pimpinan.

3. Pimpinan mengecek data obat tersebut jika pimpinan tidak menyetujui pemesanan obat maka data obat akan dikembalikan ke bagian gudang, jika pimpinan menyetujui maka akan memberikan data obat ke bagian gudang untuk melakukan pemesanan obat

4. Bagian gudang membuat data pesanan obat ke supplier.

5. Supplier mengecek ketersediaan obat, jika tidak tersedia maka data pesanan obat akan dikembalikan kepada bagian gudang, jika tersedia maka supplier mempersiapkan obat dan membuat nota pesanan obat.

6. Supplier memberikan nota pesanan ke bagian gudang.

7. Kemudian bagian gudang mencatat data obat masuk kedalam buku stok.

8. Bagian gudang memasukan obat ke apotek dan memberikan struk.

9. Apotek menerima obat dan struk tanda terima obat.

10. Bagian gudang membuat 2 laporan data obat masuk, rangkap pertama untuk pimpinan dan rangkap kedua untuk diarsipkan.

11. Pimpinan menerima laporan data obat.

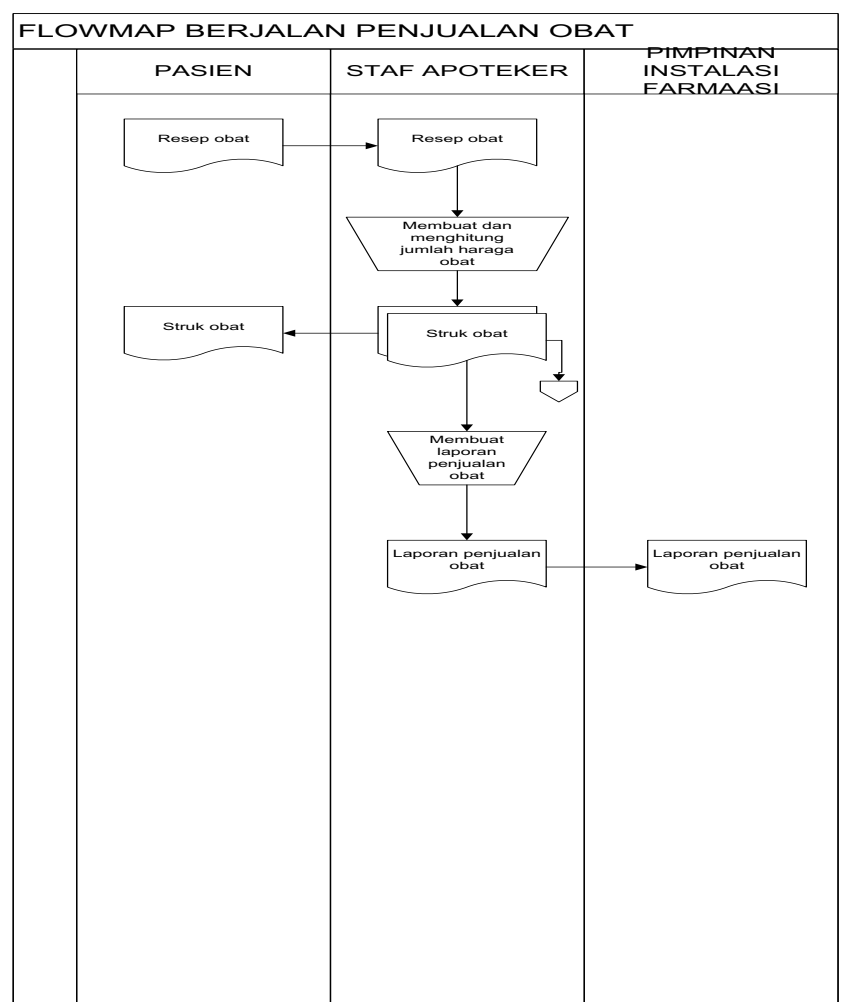

Gambar 4. Flowmap Berjalan Penjualan Obat

Prosedur Penjualan Obat Yang Sedang Berjalan:

1. Pasien datang ke apotek dan memberikan resep ke pegawai apotek.

2. Pegawai apotek membuat resep obat dan menghitung jumlah harga obat.

3. Lalu pegawai apotek menginput data penjualan obat mengunakan SIM, dan keluar 2 rangkap struk rangkap pertama untuk pasien dan rangkap kedua untuk arsip.

4. Pegawai apotek mencetak laporan penjualan dan memberikan kepada pimpinan.

\section{Flowmap Usulan}

Prosedur Penambahan Obat Usulan:

1. Melakukan proses pengecekan obat ke gudang.

2. Membuat data obat yang diberikan kepada pimpinan.

3. Pimpinan mengecek data obat tersebut jika pimpinan tidak menyetujui maka data obat dikembalikan kepada bagian gudang, jika pimpinan menyetujui maka pimpinan menyerahkan data obat tersebut kepada pegawai apotek.

4. Pegawai apotek menginput pembelian obat dan membuat form pembelian obat.

5. Supplier menerima form pembelian obat dan mengecek ketersediaan obat,jika tidak ada maka formpembelian obat akan dikembalikan, jika ada maka akan dibuat nota pembeliaan obat.

6. Supplier memberikan nota pembelian obat kepada pegawai.

7. Pegawai menginputkan data obat masuk kedalam database.

8. Pegawai mencetak 2 rangkap laporan penambahan obat dan pembelian obat, rangkap pertama untuk diserahkan kepada pimpinan dan rangkap kedua diarsipkan. 
9. Pimpinan menerima laporan.

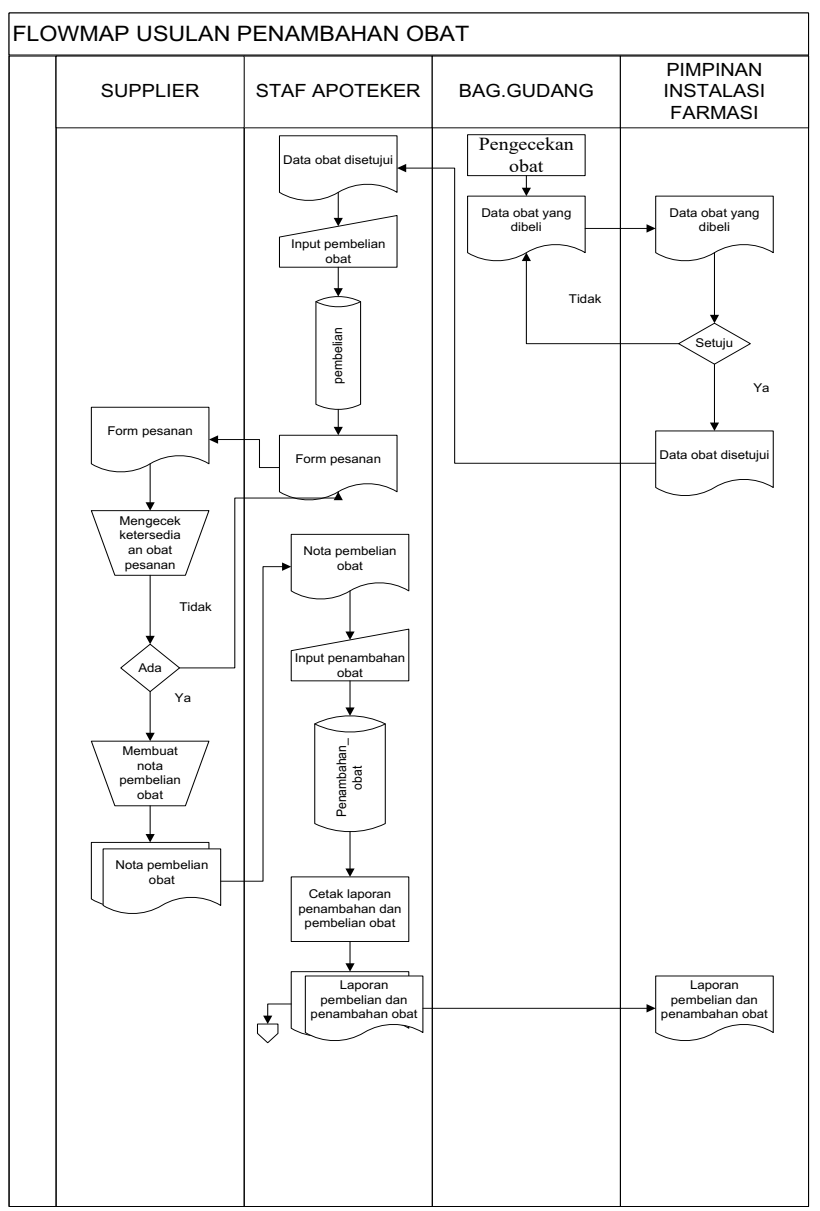

Gambar 5. Flowmap Usulan Penambahan Obat

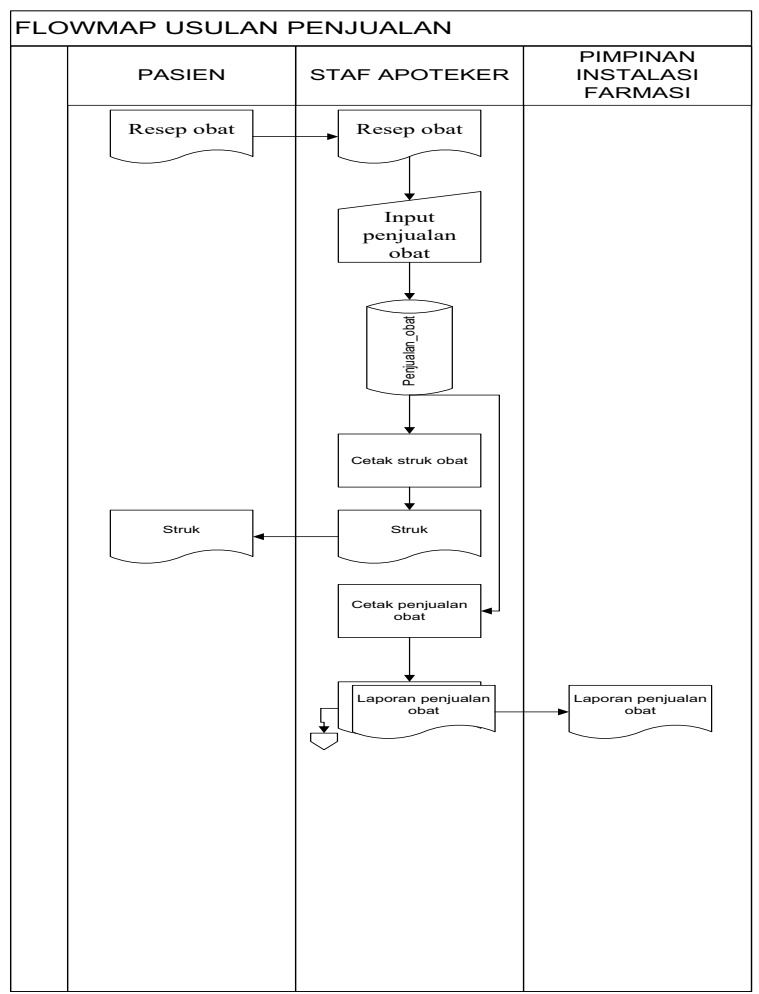

Gambar 6. Flowmap Usulan Penjualan Obat
Prosedur Penjualan Obat Usulan:

1. Pasien memberikan resep obat kepada pegawai.

2. Pegawai menginput penjualan obat kedalam database.

3. Lalu pegawai mencetak struk menjadi 2 rangkap, rangkap pertama diserahkan kepada pegawai dan rangkap kedua diarsipkan untuk dibuat laporan.

4. Kemudian pegawai akan mencetak laporan penjualan obat menjadi 2 rangkap, rangkap pertama diserahkan kepada pimpinan dan rangkap kedua diarsipkan.

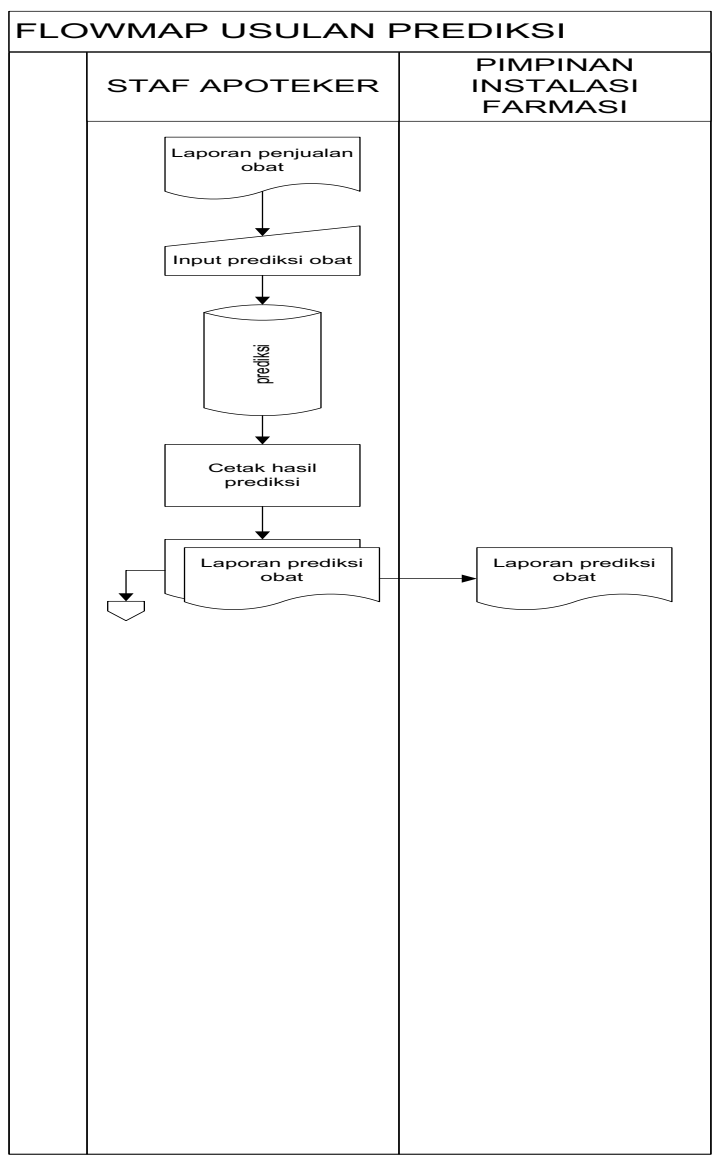

Gambar 7. Flowmap Usulan Prediksi Obat

Prosedur Penjualan Obat Usulan:

1. Pihak pegawai melakukan prediksi obat dengan cara menginputkan kedalam database jumlah stok yang keluar berdasarkan penjualan obat yang sebelumnya telah diarsipkan.

2. Pegawai mencetak hasil prediksi obat menjadi 2 rangkap, rangkap pertama diserahkan kepada pimpinan dan rangkap kedua diarsipkan 
D. Diagram Konteks

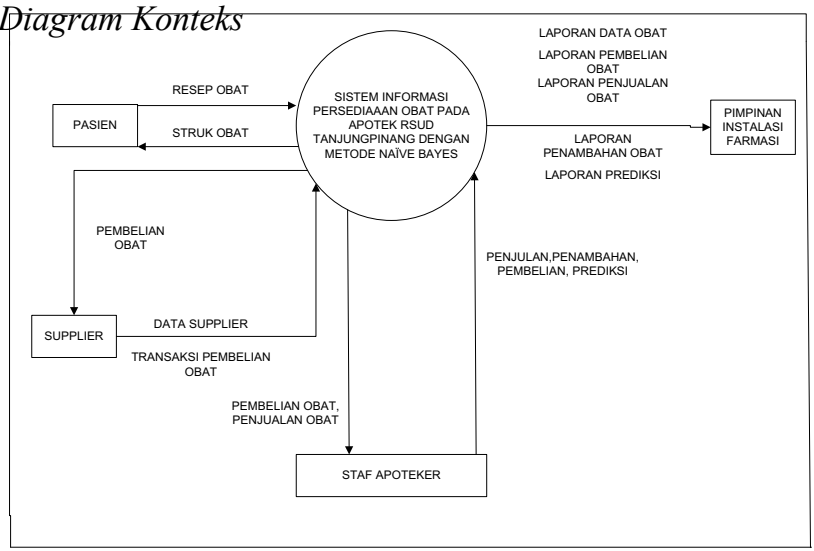

Gambar 8. Diagram Konteks

\section{E. Data Flow Diagram}

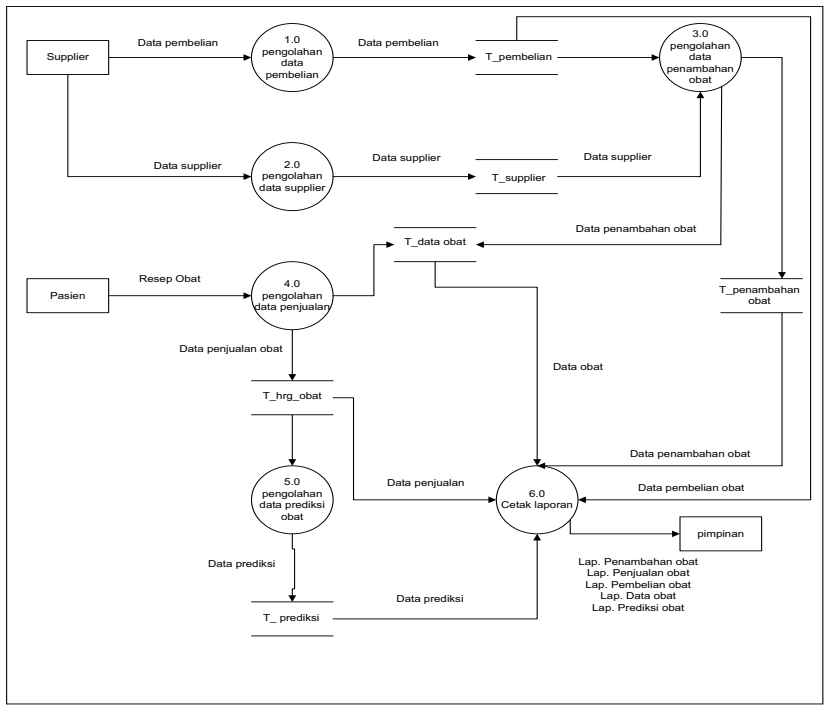

Gambar 9. Data Flow Diagram (DFD) Level 0

\section{F. Entity Relationship Diagram}

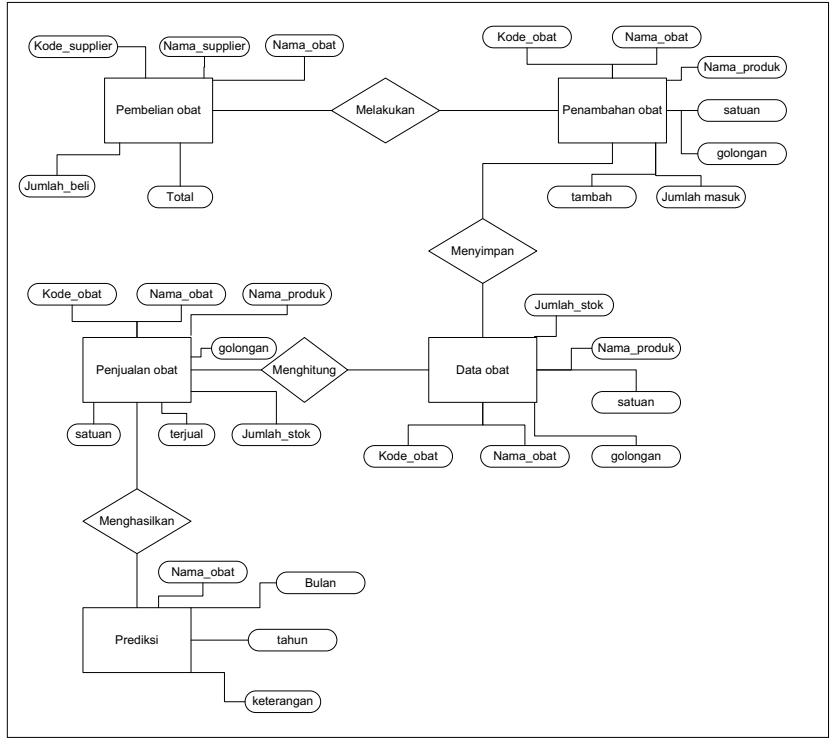

Gambar 10. Entity Relationship Diagram
G. Struktur Menu

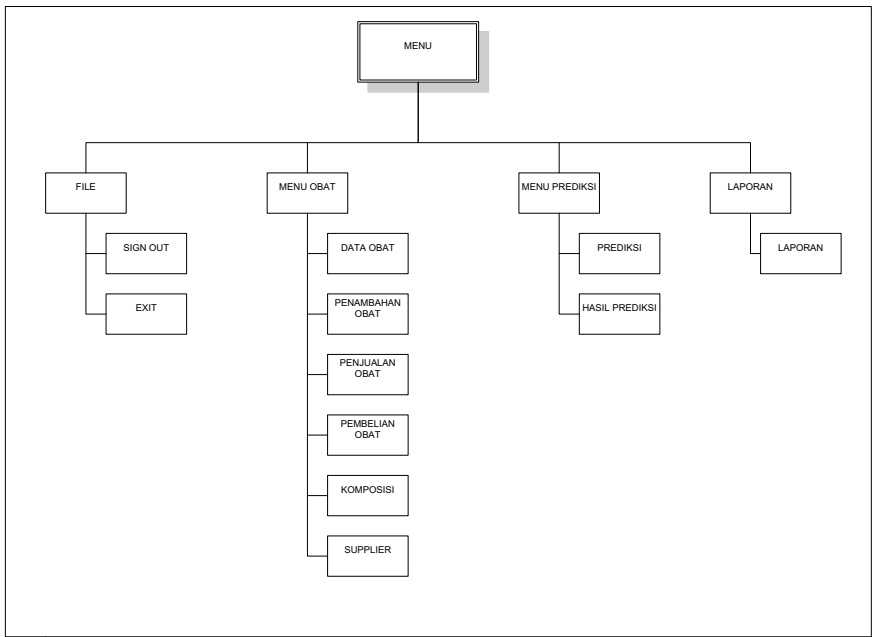

Gambar 11. Struktur Menu

Dalam struktur menu terdapat 4 menu dan sub menu lainnya yang terdiri dari:

1. File : Terdapat menu sign out untuk keluar dari program.

2. Menu obat: Terdapat menu Data obat, Penambahan obat, Penjualan obat, Pembelian obat, Komposisi, Supplier.

3. Menu prediksi : Terdapat menu Prediksi dan Hasil prediksi.

4. Laporan : Terdapat menu laporan penambahan obat, laporan penjualan obat, laporan pembelian obat, laporan prediksi obat.

\section{H. Struktur Program}

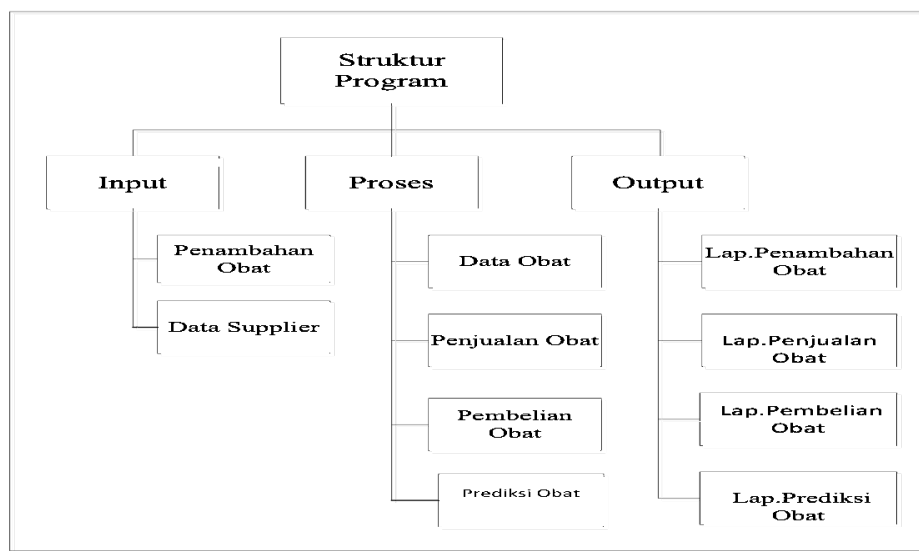

Gambar 12. Struktur Program

Dalam struktur program terdapat 3 proses yang berjalan:

1. Input : Dimana proses input untuk melakukan penambahan obat dan mendata supplier obat.

2. Proses : Melakukan proses data obat, data penjualan obat, data pembelian obat, prediksi obat.

3. Output : Berupa laporan penambahan obat, laporan penjualan obat, laporan pembelian obat, laporan prediksi obat. 


\section{Rancangan Interface}

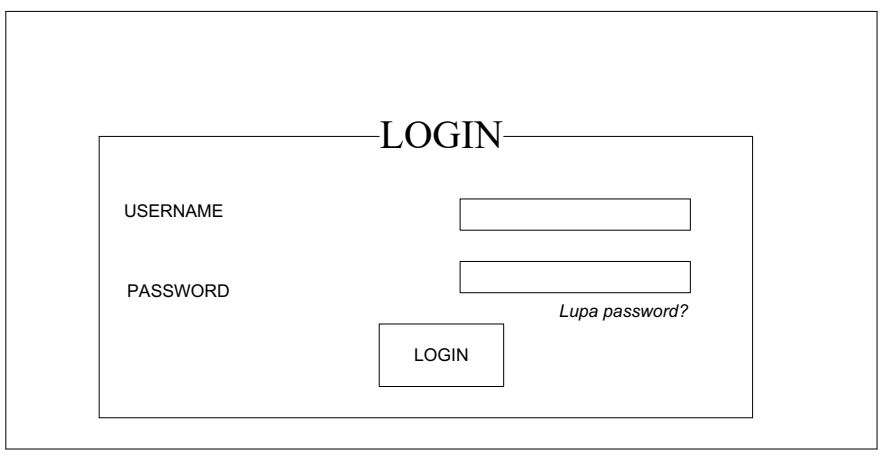

Gambar 13. Login

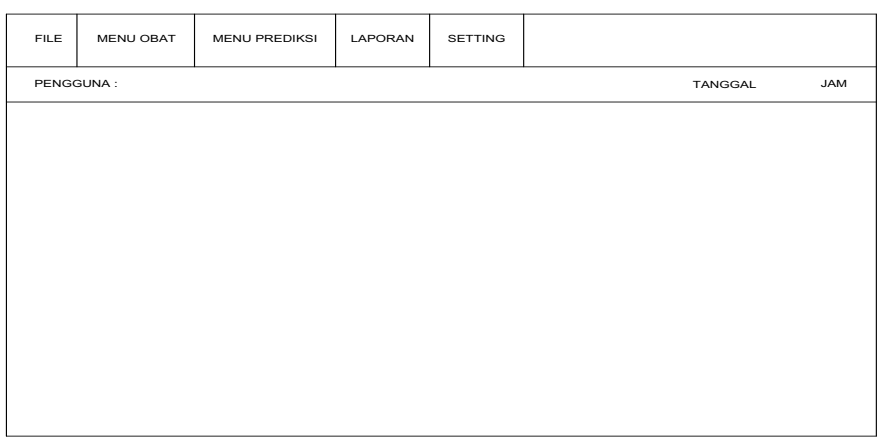

Gambar 14. Halaman Utama

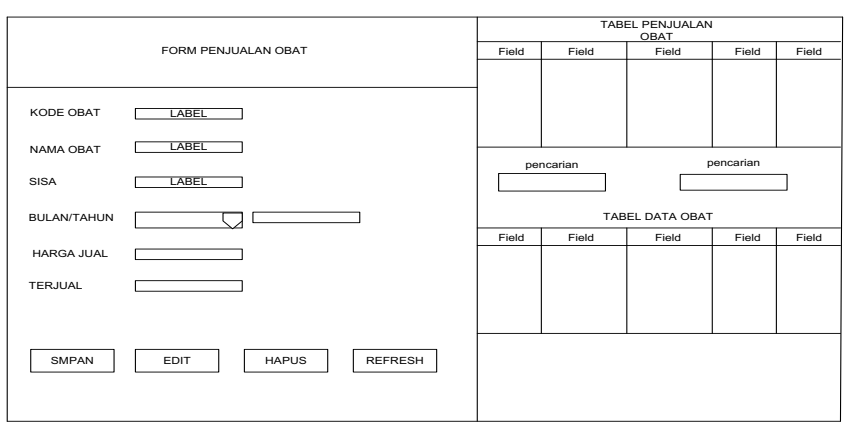

Gambar 15. Penjualan Obat

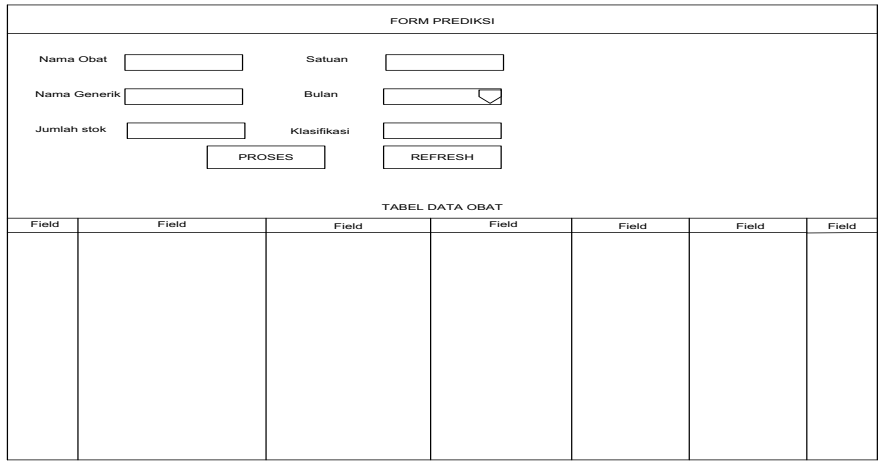

Gambar 16. Prediksi Obat

\section{KESIMPULAN}

Berdasarkan hasil proses perancangan dan implementasi perangkat lunak yang dilakukan kepada sistem, dapat disimpulkan bahwa:

Sistem Informasi Persediaan Obat pada Apotek RSUD kota Tanjungpinang menggunakan metode naive bayes dapat melakukan proses penyimpanan data persediaan obat serta transaksi penjualan dan pembelian dapat terorganisir dengan baik dalam satu sistem. Pada proses pengembangan Prediksi Persediaan Obat ini menggunakan metode naïve bayes diharapkan dapat membantu masalah dalam proses Prediksi Persediaan Obat. Laporan stok opname yang dihasilkan dapat langsung dicetak dan diberikan langsung kepada pimpinan atau diarsipkan.

\section{REFERENSI}

[1] A.H Fajar, Data Mining, Andi Offset,2013, Yogyakarta.

[2] Anonim, Panduan Penulisan Laporan KP/Skripsi(All),STT INDONESIA,2014, Tanjungpinang.

[3] Enterprise Jubilee, Java Untuk Pemula, PT Elex Media Komputindo, 2014,Jakarta.

[4] Hariyanto Bambang, M.T, Esensi - esensi Bahasa Pemograman JAVA, Informatika,2003, Bandung.

[5] Husrini \& Taufiq Luthfi Emha, Algoritma Data Mining, Andi Offset, 2009, Yogyakarta.

[6] Presman, Roger, Rekayasa Perangkat Lunak Pendekatan Praktisi, 2012, Yogyakarta.

[7] Yakub, Pengantar Sistem Informasi, 2012, Yogyakarta.

[8] Yesin Verdi,S.Kom, Rekayasa Perangkat Lunak Berorientasi Objek Pemodelan, Arsitektur dan Perancangan (Modeling, Architecture and Design), 2012, Jakarta.

[9] Furqan Muhammad, Wibowo H Sastia, S. Kom, M. Kom, Abdullah Dedy, ST. M, Eng. SISTEM PERSEDIAAN OBAT PADA PUSKESMAS MENGGUNAKAN METODE NAÏVE BAYES (STUDI KASUS PUSKESMAS TALANG TINGGI SELUMA),2013[Online] Tersedia:https://leerpdf.com/index.php/download/sistem-persediaanobat-pada-puskesmas-menggunakan-metode-nave-bayes-studi-kasuspuskesmas-talang-tinggi-seluma-_592dd2431723dd85fbc08283_pdf [22 februari 2017].

[10] Nofriansyah Dicky, Erwansyah Kamil, RamadhanEng Mukhlis. Penerapan Data Mining dengan Algoritma Naive Bayes Clasifier untuk Mengetahui Minat Beli Pelanggan terhadap Kartu Internet XL (Studi Kasus di CV. Sumber Utama Telekomunikasi),2016[Online] Tersedia:https://lppm.trigunadharma.ac.id/public/fileJurnal/hpgu $1 \% 20$ Dicky_Mei2016.pdf [22 Agustus 2017].

[11] Hasil wawancara

[12] S. M. Metev and V. P. Veiko, Laser Assisted Microtechnology, 2nd ed., R. M. Osgood, Jr., Ed. Berlin, Germany: Springer-Verlag, 1998.

[13] J. Breckling, Ed., The Analysis of Directional Time Series: Applications to Wind Speed and Direction, ser. Lecture Notes in Statistics. Berlin, Germany: Springer, 1989, vol. 61.

[14] S. Zhang, C. Zhu, J. K. O. Sin, and P. K. T. Mok, "A novel ultrathin elevated channel low-temperature poly-Si TFT," IEEE Electron Device Lett., vol. 20, pp. 569-571, Nov. 1999. 